\title{
Advocacy group effects in global governance: populations, strategies, and political opportunity structures
}

\author{
Lisa M. Dellmuth ${ }^{1}$ - Elizabeth A. Bloodgood ${ }^{2}$
}

(c) The Author(s) 2019

\begin{abstract}
Global governance is no longer a matter of state cooperation or bureaucratic politics. Since the end of the cold war, advocacy groups have proliferated and enjoyed increasing access to global governance institutions such as the European Union, World Trade Organization, and the United Nations climate conferences. This special issue seeks to push theories of interest groups and international non-governmental organizations forward. We argue that the advocacy group effects on global governance institutions are best understood by examining how groups use and shape domestic and global political opportunity structures. The individual articles examine how, when, and why domestic and global political opportunity structures shape advocacy group effects in global governance, across global institutions, levels of government, advocacy organizations, issue areas, and over time. As special interests are becoming increasingly involved in global governance, we need to better understand how advocacy organizations may impact global public goods provision.
\end{abstract}

Keywords Advocacy · Global governance institutions · Interest groups · International non-governmental organizations · Political opportunity structures · Salience $\cdot$ Complexity $\cdot$ Venue shopping $\cdot$ Population ecology

\section{Introduction}

Biodiversity losses, epidemics, financial crises, hunger, illegal fishing, migration, and violent conflict- these are only a few examples of the complex and trans-boundary policy challenges that states are facing in today's global world. To address such challenges, states have over the past three decades delegated increasing power to global governance institutions (GGIs) such as the climate conferences of the United

Lisa M. Dellmuth

lisa.dellmuth@su.se

1 Department of Economic History and International Relations, Stockholm University, 10691 Stockholm, Sweden

2 Department of Political Science, Concordia University, Montreal, QC H3G2M8, Canada 
Nations (UN), the European Union (EU), or the World Trade Organization (WTO). As multilateral institutions that establish authoritative rules, GGIs affect domestic and global governance through mechanisms such as economic coercion, information provision, norm socialization, and social shaming (Barnett and Finnemore 2004; Buchanan and Keohane 2006).

Given their importance for solving policy problems, GGIs have increasingly become the target of advocacy organizations (Reimann 2006; Bloodgood 2010; Dellmuth and Tallberg 2017). Almost 5000 international non-governmental organizations (INGOs) have consultative status in the United Nations (UN) (2016); close to 8000 INGOs are now listed in the interest group register of the European Union (EU) (2018); and hundreds of INGOs attend the ministerial meetings and conferences of the WTO (Hanegraaff et al. 2011), UN climate summits (Hanegraaff 2015), regional fisheries management organizations (Petersson et al. 2018), and World Bank (2018). Yet, despite the proliferation of advocacy organizations in global governance, their effects on GGIs have been insufficiently recognized, conceptualized, and examined (see also Stevenson 2016; Tallberg et al. 2018).

This special issue seeks to increase our understanding of the aims, strategies, and effects of advocacy groups on GGIs' policy and implementation. Articles address questions: Is advocacy best targeted nationally or globally, and what determines which venue is selected? Do domestic institutions and resource levels drive advocacy group lobbying success in GGIs? Do advocacy groups build strategic coalitions to impact GGIs? When and why do transnational partnerships shape the implementation of GGI policymaking? How do advocacy groups use global opportunity structures to shape domestic and global public goods provision? To what extent can globally active advocacy groups shape their national political opportunity structures, if at all? Establishing answers to these questions will push interest group and INGO theories forward at the same time enhancing our empirical understanding of the nature of advocacy group populations, the GGIs they choose to target, the strategies they use for advocacy, and their effects on GGIs policymaking and the implementation of global norms and rules domestically.

We conceptualize advocacy groups as nonprofit or profit interest organizations that may pursue domestic or global strategies, or adopt a mix of domestic and global strategies, to achieve their goals. We thus focus on advocacy not only with the aim to affect government policy (Baumgartner and Leech 1998) but also to influence the public good more generally (Skjelsbaek 1971; Feld 1972; Stroup 2012). Indeed, INGOs do often but not always seek to influence public policy, but still have political aims (Hadden 2015; Heiss and Johnson 2016; Dellmuth and Tallberg 2017; Stroup and Wong 2017).

The targets of all groups examined in this special issue, albeit potentially indirectly via the national level, are GGIs. GGIs are multilateral entities, including intergovernmental organizations (IGOs), such as the EU and WTO, standard setting bodies, such as the Basel Committee on Banking Supervision (BCBS) and International Standards Organization (ISO), and multi-stakeholder institutions, such as the Forest Stewardship Council (FSC), UN Sustainable Development Goals, and Marine Stewardship Council (MSC), which formally include non-governmental actors as well as state representatives. 
In this special issue, we examine advocacy group effects on various outcomes. First, advocacy groups have effects on organizational populations at the global level. Second, we focus on advocacy groups' strategies, which determine how groups seek influence in GGIs, including advocacy toward a GGI directly or via national government representation in a GGI. Third, we investigate advocacy group effects on the implementation of GGI norms and rules at the national level.

This introduction develops a theoretical framework on the conditions under which advocacy groups, constrained or enabled by domestic and global political opportunity structures, can affect GGIs and their policymaking and implementation. In today's complex and polycentric institutional architecture in global governance, opportunity structures are central in shaping outcomes. Our framework draws on interest group theory in comparative (and American) politics (see Dür and de Bièvre 2007; Hojnacki et al. 2012, for overviews) and INGO theory as developed in International Relations (see Risse 2012 for an overview). The articles in the special issue demonstrate how our framework can be used to advance key claims in interest group and INGO theories. Here, we focus on how INGO theories of institutional complexity and outside strategies can advance on interest group research, and how interest group theories of venue shopping and information-access exchange can develop INGO research. Through ambitious research designs in multiple policy areas, including development, diplomacy, environmental governance, economic governance, internet governance, and social justice, articles engage with their research questions by examining advocacy group politics across global institutions, levels of government, types of advocacy organizations, issue areas, and over time. Two concluding articles discuss our contribution critically in light of the nature of interest representation beyond the nation-state and the implications of special interest effects for the quality of global governance.

\section{Contrasting accounts of advocacy group effects}

To date, interest group and INGO research have made only sporadic contact, despite a strong potential for highly productive cross-fertilization. This section examines differences in these two literatures in order to identify several missed opportunities.

\section{Theories of interest groups and INGOs}

In terms of the goals of advocacy groups, while interest groups are defined as formally organized groups outside of the government system yet seeking to exert influence on the function or composition of government and its outputs (e.g., Beyers et al. 2008; Berry and Wilcox 2005, p. 5; Baroni et al. 2014), INGO are typically defined as voluntarily organized actors with members, funding, and activities from multiple countries acting in the interest of public benefit (e.g., Skjelsbaek 1971; Feld 1972; Keck and Sikkink 1998; Martens 2002; Heiss and Johnson 2016). The category INGO is generally not seen to include industry or business groups or labor unions (Martens 2002; Stroup and Wong 2017), while these are fair game to be viewed as interest groups (Baroni et al. 2014). Some 
INGOs are organizations that only provide services (Murdie and Davis 2012), while definitions of interest groups generally require explicitly political behavior (Beyers et al. 2008). However, recent years have seen increasing recognition of INGOs' advocacy orientation, practical motivations, and organizational imperatives for survival (e.g., Cooley and Ron 2002; Sell and Prakash 2004; Bob 2005; Bloodgood 2010; Prakash and Gugerty 2010; Mitchell and Schmitz 2014; Stroup and Wong 2017; Dellmuth and Tallberg 2017; Tallberg et al. 2018).

With respect to strategies, INGOs are traditionally seen as limited in their behavior by their lack of economic or coercive power to the use of strategies of normative pressure and information monitoring intended to shift state behavior via issue framing, agenda setting, and norm diffusion (Keck and Sikkink 1998; Brysk 2002; Clark 2001; Risse et al. 2015; Heiss and Johnson 2016; Stroup and Wong 2017). By contrast, interest group scholars typically focus on different types of inside and outside strategies of lobbying according to whichever is perceived most effective at putting pressure on government actors to shift their policy (Chalmers 2013; Binderkrantz et al. 2015; Hanegraaff et al. 2016; Dellmuth and Tallberg 2017; Dür and Mateo 2013).

Moreover, INGO and interest group scholars expect their respective organizations to exert effects on policy and practice at different phases of the policymaking cycle. INGO scholarship tends to focus on the earliest and latest stages of the process, namely agenda setting and monitoring compliance (Carpenter 2007; Hendrix and Wong 2012; Risse 2012). Interest group scholars have examined the full range from agenda setting to enforcement, but tend to concentrate on specific phases of the process in which lobbying is most present (decision making itself) (Halpin 2002; Lowery et al. 2008; Hanegraaff et al. 2016).

Last, the extent to which advocacy groups are expected to adapt their strategies based on political opportunity structures varies significantly. Institutional context is crucial within the interest group literature, as the choice between inside versus outside lobbying depends on the interaction between institutions in which the organization finds itself, and thus its access and available strategies (Mahoney and Baumgartner 2008; Hanegraaff et al. 2016; Dellmuth and Tallberg 2017). INGO research tends to focus on the ability of organizations to shape preferences according to norms internalized into individual and government practice (Finnemore and Sikkink 1998; Risse et al. 2015) in which compliance is largely voluntary (according to self-interest or a sense of appropriate behavior) to standards set by non-state and state actors together (Green and Auld 2017; Prakash and Potoski 2014). The INGO literature has traditionally assumed a confrontational relationship between INGOs and states (Stroup and Wong 2017), and thus, the institutional context in which INGOs operate is typically seen as thinner and less important (Heiss and Johnson 2016). This is largely due to the prominence of the boomerang model within INGO research, as INGOs can use their networks to boomerang around institutional obstacles (Clark 1995; Keck and Sikkink 1998; Florini 2000; Brysk 2002; Risse et al. 2015). 


\section{Missed opportunities for theoretical exchange}

The gaps between the interest group and INGO literatures have resulted in several missed opportunities for theoretical and empirical advancements that this special issue seeks to exploit. Here, we outline how the theories could inform each other. In the ensuing section, we will develop ideas for the conditions under which advocacy groups' effects on GGIs occur by drawing on the exchange between these literatures.

First, interest group theories can benefit from INGO scholars work on governance beyond the state (c.f. Avant et al. 2010; Scholte 2017). In particular, venue shopping theory could be developed by greater engagement with IR literatures on polycentric governance and regime complexity. States often take a backseat in polycentric regimes and benefit from advocacy groups who provide information and policy ideas (Scholte 2017), while institutional complexity provides interest groups with a greater variety of strategies in the design of their advocacy campaigns (Keohane and Victor 2011; Green and Auld 2017; Allan and Hadden 2017). Overlapping regimes create the potential for new issue linkages that may enable a new range of bargaining solutions (Davis 2004), and fragmented governance architectures open up new modes of policy contestation (Zelli 2011; Orsini 2013) and bring together interesting new coalitions and partnerships of advocacy groups (Yanacopulos 2005; Chalmers 2013; Beyers and Hanegraaff 2017). Thus, not only are the available options for venue shopping greater when global polycentric arenas for policymaking are explored (Pralle 2006; Joachim 2007; Chalmers 2013; Pallas and Uhlin 2014), but also political contestation, state interests, political opportunity structures, and thus the nature of advocacy group strategies and influence are likely to differ.

Second, the inclusion of theories from INGO scholarship introduces a broader set of strategies that advocacy groups might adopt, in particular alternative forms of outside advocacy such as networking, mass demonstration, protest actions, and litigation (c.f. Dalton 1994; Betsill and Corell 2008; Murdie and Davis 2012). Advocacy groups pursuing global strategies have different constellations of interests that may enable new types of and broader coalitions for successfully applying pressure in national and global arenas, which are often overlooked by interest group scholars (Carpenter 2007, 2011; Busby 2007; Bob 2012; Hadden 2015). Larger networks of advocacy groups may be able to apply pressure to multiple national and GGI decision makers simultaneously across venues and issue frames for greater effect. While inside strategies are similar across the interest group and INGO literature, INGO scholarship delves more deeply into the alternatives that organizations pursue when direct access to decision-making processes is blocked, including "naming and shaming" campaigns and dramatic protests and mass demonstrations (Hadden and Jasny 2019; Hendrix and Wong 2012; Keck and Sikkink 1998; Bob 2005).

In turn, we identify two main ways in which INGO theories can learn by drawing on interest group theories. First, by acknowledging the importance of institutions in shaping advocacy group activities and effects, INGO scholars could better understand how global advocacy group populations mobilize and impact global governance. While INGO research incorporates insights from theories of gatekeeping (Busby 2007; Carpenter 2011), there is much to be done. INGOs may "boomerang" in the international system to work around obstacles, but they also need to respond 
to institutional opportunities and constraints when they select where to engage with institutions (Bloodgood and Clough 2017). Horizontal and vertical venue shopping theories from interest group studies help to sharpen expectations for the conditions under which organizations will seek to influence policy in global, regional, or national institutions, and when organizations will select between alternative GGIs for more favorable conditions according to issue position, ideology, or formal access rules (Bolleyer and Börzel 2010; Baumgartner and Jones 1993).

Second, interest group theory on how institutions may shape advocacy group access and influence and the resources needed by policymakers (cf. Dür and de Bièvre 2007) could be fruitfully further developed in the global context. Insights from exchange theory of interest group influence, with its associated focus on the conditions under which different types of information enable interest groups access to decision-making institutions and processes will help INGO scholars to develop more advanced theories of INGO influence in global governance (Dellmuth and Tallberg 2017; Tallberg et al. 2013; Bloodgood 2010).

\section{Political opportunity structures and advocacy group effects}

Building on the above-identified areas that promise fruitful cross-fertilization between interest group and INGO theory, the central argument of this special issue is that domestic and global political opportunity structures enable and constrain the effects of advocacy groups on GGIs in terms of policymaking and implementation at both the domestic and global levels. Political opportunity structures, originating from social movement research (e.g., Tarrow 2005), are widely used to understand the roles of INGO in global governance. Opportunity structures refer to specific institutional arrangements, resource configurations, and policy environments that may shape advocacy group mobilization, strategies, and effects (e.g., Tarrow 2005; Skodvin and Andresen 2008; Prakash and Gugerty 2010; Hadden and Jasny 2017). Putting opportunity structures center stage allows for theorizing the conditions under which advocacy groups mobilize, target GGIs (and the GGIs they target), and shape GGIs' political outcomes. Below we will develop our understanding of these conditions in the three categories of opportunity structures: institutional arrangements, resource configurations, and policy environments.

\section{Institutional arrangements}

It is common for institutional explanations to assume that rules, norms, and procedures enabling advocacy group involvement in governance structure advocacy group effects (e.g., March and Olsen 1984; Dür and de Bièvre 2007). At the domestic level, democracy is an important factor shaping advocacy group mobilization globally (Smith and Wiest 2005; Lee 2010). Advocacy group populations are likely to be larger from democratic countries given higher levels of political openness and less repression of civil society (Stroup 2012; Dupuy et al. 2016; Heiss and Johnson 2016). Indeed, advocacy groups from democratic countries are more likely to engage in inside lobbying since they may have access to policymakers at national 
and global levels (Hanegraaff et al. 2016). However, it is debated whether increased access to GGI policymakers leads to influence at global venues, as there may be less need for information from these groups and more noise given all of the groups participating in a democratic context (Lohmann 1998; Tallberg et al. 2018). Added advocacy group participation from authoritarian countries may provide new meaningful information given the relative difficulty and risk of participation in non-democratic contexts (Bernauer et al. 2014; Heiss and Johnson 2016). Thus, while advocacy groups from democratic countries are more likely to engage in inside lobbying in GGIs, their lobbying strategies may not be as effective.

Furthermore, democracy in GGIs conceptualized as relatively generous access rules does not necessarily imply that advocacy groups have more influence on political outcomes. One reason may be that GGIs with generous access rules see participation by a larger number and variety of advocacy groups, which may increase the potential for countervailing lobbying (Austen-Smith and Wright 1994; Baumgartner and Leech 1998). In addition, GGIs with more access may also require larger winning coalitions to effect policy change (Evangelista 1999; Risse-Kappen 1995). GGIs having more restrictive access rules may lead to participation by smaller and more homogenous populations of advocacy groups and face fewer veto points and therefore have greater effects on political outcomes (cf. Bernauer et al. 2014). In light of these considerations, we expect GGIs with more generous access rules to lead to greater participation by more and more diverse advocacy groups' populations, but it remains an empirical question whether this strengthens or weakens group effects on GGI policy or behavior.

\section{Resource configurations}

There is evidence that advocacy groups are more likely to participate in global policymaking if they are relatively well endowed in terms of resources (Dellmuth and Tallberg 2017). While national economic factors, most notably level of economic development, can impact the level of available resources for advocacy groups, the relationship is rarely a direct or linear one. National institutions, including tax and lobbying laws, have differential effects on the resources available to specific types of advocacy groups. In addition, selective government funding is an important source of advocacy group mobilization (Dür and Mateo 2013; Beyers et al. 2008; Bloodgood and Tremblay-Boire 2017). Resources, in turn, may allow for group effects in global governance due to structural power (Bernhagen and Bräuninger 2005), personnel and finances (McCarthy and Zald 1978), information (Lohmann 1998; Bouwen 2002; Tallberg et al. 2018), and group leadership (Halpin and Jordan 2009). We expect greater availability of resources for an advocacy group to be positively related to that group's effects on GGIs.

Coalition building may also increase advocacy group effects on policymaking and implementation by combining forces to compensate for individual weaknesses (Betsill and Corell 2008; Klüver 2011; Lindgren and Persson 2011). Coalitions might include different types of advocacy groups, including business or industry associations, charitable or public benefit organizations, or civil society organizations, and might include organizations with different preferences around different aspects of 
the issue at hand (Lowi 1964; Dür and de Bièvre 2007). The central expectation is that advocacy groups may have greater effects when seeking to influence issues where they represent homogenous interests and where there are few counter-lobbies. Networking, or the existence of powerful gatekeeping organizations, may allow organizations to bridge their differences and encourage the adoption of common frames, producing more homogenous and focused issue campaigns (Busby 2007a, b; Carpenter 2007, 2011; Allan and Hadden 2017). The nature of the policy may assist or stymie coalition building. While regulatory policy may produce both dedicated advocates and opponents, distributive policy is likely to generate concentrated constituencies with a positive stake in the policy, making advocacy group effects more likely, but redistributive policy can be expected to produce both diffuse costs and diffuse benefits, making interest group mobilization and effects less likely.

\section{Policy environment}

We focus on two aspects of policy environments that interest group theory has shown to matter for group effects: complexity and salience. Complexity refers both to the extent to which a policy problem is difficult to analyze, understand and solve, and the number of multilateral institutions relevant to the operation of the policy area (Keohane and Victor 2011; Morse and Keohane 2014). The complexity of an issue increases according to the number of distinct actors involved (public agencies, types of private actors, and policymaking domains); the extent to which technical knowledge is needed to diagnose or solve the problem; and the fragmentation of the institutional context or regime. The greater the complexity of a policy problem, the more likely it is that international policymakers will lack sufficient information, and the greater the probability that they will rely on information provided by advocacy groups (McNamara 1999; Tallberg et al. 2018). However, with more complexity and nuance, and higher degrees of overlap across relevant international regimes and GGIs, there is also more space for advocacy groups to pursue advocacy. For example, new coalitions may arise that are built on different aspects of an issue and that may work against each other (Hadden 2015; Allan and Hadden 2017). This logic suggests that the more complex the institutional landscape, and thus the larger the number of GGIs dealing with the issue, the more likely advocacy groups are to create large, heterogeneous coalitions with shared interests and the greater the number of possible GGIs to target with their advocacy. This should lead to greater advocacy group effects.

Salience may be understood in three different ways: salience to states, advocacy groups, and the general public. While the different uses of salience in the previous literature make it difficult to develop a consistent theoretical expectation, several lines of reasoning are discernible. If a policy is highly salient to member states, then they are less likely to take the interests and concerns of advocacy groups into consideration, as compared to when they care less about the policy issue. This logic is often stated in terms of market failures: INGOs as non-state, non-market actors are expected to fill in the gaps in state and market activity, providing services, including interest representation, where states and markets are not interested or able (Prakash and Gugerty 2010). Others, however, have argued that advocacy groups serve as 
service bureaus and thus advocacy groups follow where states lead, essentially making their effects epiphenomenal (Skjelsbaek 1971; Mearsheimer 1994; Baumgartner and Leech 1998; Raustiala 1997). Interest group populations, according to these scholars, are expected to be the most active in areas where states are active. Indeed, on more salient issues, there are more likely to be advocacy groups active on different sides of the issue. Yet others have argued that in the eyes of stakeholder organizations, GGIs are more democratic in terms of deliberation, representation, and accountability, the more states care about a specific policy issue, contradicting a widespread suspicion that democracy is something that states "can afford" when real interests are not at stake (Agné et al. 2015).

In terms of issue salience to citizens, an issue enjoying high salience among states may be of limited interest to specific citizen groups. Interest groups, in turn, have been shown to also play a key role in shaping the public salience of issues (Dür and Mateo 2013). In turn, issue salience to advocacy groups increases the influence of groups that form part of the relatively large lobbying coalition on the issue and decreases the influence of groups that belong to the relatively small coalition (Klüver 2011; see Beyers et al. 2017 for an overview). These bodies of literature each generate different expectations with regard to how issue salience may shape interest group strategies and their effects. It is possible that the more salient a policy issue, the larger the global population of interest groups active in that issue. But, the expected positive relationship between issue salience and advocacy group effects on GGI policymaking and implementation may be weakened when issue salience generates effective counter-lobbying.

\section{Article overview}

While advocacy group effects on GGIs are central to this special issue, we are agnostic on the best way to study them methodologically. Rather, the papers are organized in two parts. The first set of articles focuses on advocacy group effects in terms of the nature of advocacy group populations at the global level. The second set of articles examines advocacy group effects on advocacy groups' choices of strategies and venues, with implications for GGIs' policy and implementation.

In the first part, Joost Berkhout and Marcel Hanegraaff focus on the institutionalization of bias in advocacy group mobilization across issue areas and levels of governance. They develop and test an argument for why some issue areas are more strongly biased toward business interests than others, and explore why this observation does not extrapolate to the global level.

The article by Laura Henry, Lisa McIntosh Sundstrom, Priya Bala-Miller, and Carla Winston maps participation by INGOs from BRICS states (Brazil, Russia, India, China, and South Africa) in GGIs. The evidence reveals that participation patterns reflect incentives and pressures at global and national levels, including the design of the GGI and INGO capacity linked to domestic conditions. The article argues that opportunity structures at both levels shape INGOs' participation in GGIs and thus their potential to influence GGI policy. 
Nina Hall explores the role of digital advocacy organizations in campaigning for refugee rights. She demonstrates that the internet has led to new forms of advocacy organization that have professional, permanent staff like INGOs, but their mode of advocacy starkly differs. Hall highlights how digital advocacy organizations choose their campaigns primarily based on issue salience to their members, whereas traditional NGOs are driven by issue expertise in campaign decision making.

Andrew Heiss examines how the spread of increasingly restrictive national regulation of INGOs has a serious impact on the nature of global advocacy group populations and their ability to affect national or GGI policy. He explores efforts by global advocacy organizations to push back against national regulations which shape INGOs' political opportunity structures in inopportune ways. In order to maximize their choices of venues for advocacy, INGOs need to maintain programmatic flexibility by ensuring favorable resource configurations.

In the second set of articles, Mette Eilstrup-Sangiovanni examines the effects of increasing density in global advocacy group populations on the strategies that different types of INGOs use to compete for resources and influence global policy in GGIs. Using population ecology theories, she argues that a complex division of labor has emerged between larger, generalist INGOs that seek conventional resources and use moderate tactics toward mainstream goals, and smaller specialist organizations that focus on "niche" issues, and often adopt more radical strategies and tactics.

Kirsten Lucas, Marcel Hanegraaff, and Iskander De Bruycker build on resource exchange theory and the concept of political opportunity structures to explain when policymakers target allied or opposing advocacy groups. Through novel interview data with 297 policymakers at global climate change and trade conferences, they demonstrate that policymakers target both groups when faced with increased levels of political pressures. Moreover, policymakers from democratically accountable countries and those working on salient issues are more inclined to reach out to allied advocacy groups.

Adam W. Chalmers and Adela Iacobov examine the factors that incentivize advocacy groups to seek access to GGI policy venues responsible for regulating the financial industry. They argue that a firm's cross-border business activities explain the extent of its GGI venue shopping. The main findings suggest that the more geographically dispersed the cross-border activities of a firm are, the more global venues it is likely to target in order to shape Basel III, Capital Requirements Directive (CRD)IV, and Capital Requirements Regulation (CRR) regulations.

Finally, Matilda Petersson explores the role and behavior of transnational partnerships in shaping strategies in and outcomes of global fisheries governance. Focusing on the case of illegal, unreported, and unregulated (IUU) fishing, the article theorizes and empirically explores the variation in strategies used by transnational partnerships to shape IUU policy and implementation, by drawing on advocacy group and INGO literature.

The special issue concludes with two critical contributions on the nature of interest representation beyond the nation-state and the implications for the quality of domestic and global governance. (Jan Aart Scholte: "Civil society and global 
governance. Exploring transscalar connections" and Darren Halpin: "Close cousins, or false friends? Studying interest groups and INGOs").

In all, this special issue seeks to set the agenda in research on global effects of interest groups at the intersection of comparative politics and IR, demonstrating how research problems unaddressed in both fields can be fruitfully examined and theory be advanced through greater cross-fertilization.

Acknowledgements The authors extend warm thanks to the participants of the special issue workshop at Stockholm University in June 2018 and the participants of the Higher Research Seminar at the Department of Economic History and International Relations at Stockholm University in April 2018. The authors made the creation of this special issue a very enjoyable and rewarding experience. We also thank Tristan Masson for excellent research assistance and gratefully acknowledge the funding of Riksbankens Jubileumsfonds (F17-1189:1).

\section{Compliance with ethical standards}

Conflict of interest The authors declare that they have no conflict of interest.

Open Access This article is distributed under the terms of the Creative Commons Attribution 4.0 International License (http://creativecommons.org/licenses/by/4.0/), which permits unrestricted use, distribution, and reproduction in any medium, provided you give appropriate credit to the original author(s) and the source, provide a link to the Creative Commons license, and indicate if changes were made.

\section{References}

Agné, H., L.M. Dellmuth, and J. Tallberg. 2015. Does Stakeholder Involvement Foster Democratic Legitimacy in International Organizations? An Empirical Assessment of a Normative Theory. Review of International Organizations 10: 465-488.

Allan, J., and J. Hadden. 2017. Exploring the Framing Power of NGOs in Global Climate Politics. Environmental Politics 26(4): 600-620.

Austen-Smith, D., and J. Wright. 1994. Counteractive Lobbying. American Journal of Political Science 38(1): 25-44.

Avant, D., M. Finnemore, and S. Sell (eds.). 2010. Who Governs the Globe?. Cambridge: Cambridge University Press.

Barnett, Michael, and Martha Finnemore. 2004. Rules for the World: International Organizations in Global Politics. Ithaca: Cornell University Press.

Baroni, L., B. Carroll, A. Chalmers, L. Munoz Marquez, and A. Rasmussen. 2014. Defining and Classifying Interest Groups. Interest Groups and Advocacy 3(2): 141-159.

Baumgartner, F.R., and B.D. Jones. 1993. Agendas and Instability in American Politics. Chicago: The University of Chicago Press.

Baumgartner, F.R., and B. Leech. 1998. Basic Interests. Princeton, NJ: Princeton University Press.

Bernauer, T., T. Böhmelt, and V. Koubi. 2014. Is There a Democracy-Civil Society Paradox in Global Environmental Governance ? Global Environmental Politics 13(1): 88-107.

Bernhagen, P., and T. Bräuninger. 2005. Structural Power and Public Policy: A Signalling Model of Business Lobbying in Democratic Capitalism. Political Studies 53(1): 43-64.

Berry, J., and W. Wilcox. 2005. The Interest Group Society. Harlow: Longman Press.

Betsill, M., and E. Corell. 2008. NGO Diplomacy: The Influence of Nongovernmental Organizations in International Environmental Negotiations. Cambridge, MA: The MIT Press.

Beyers, J., A. Dür, and A. Wonka. 2017. The Political Salience of EU Policies. Journal of European Public Policy. https://doi.org/10.1080/13501763.2017.1337213.

Beyers, J., R. Eising, and W. Maloney. 2008. Researching Interest Group Politics in Europe and Elsewhere: Much We Study, Little We Know? West European Politics 31(6): 1103-1128. 
Beyers, J., and M. Hanegraaff. 2017. Balancing Friends and Foes: Explaining Advocacy Styles at Global Diplomatic Conferences Voice and Access. Review of International Organizations 3. https://doi. org/10.1007/s11558-016-9262-z.

Binderkrantz, A.S., P.M. Christiansen, and Helene Helboe Pedersen. 2015. Interest Group Access to the Bureaucracy, Parliament, and the Media. Governance 28(1): 95-112.

Bloodgood, E. 2010. The Interest Group Analogy: International Non-governmental Advocacy Organizations in International Politics. Review of International Studies 37(1): 93-120.

Bloodgood, E., and E. Clough. 2017. Transnational Advocacy Networks: A Complex Adaptive Systems Simulation Model of the Boomerang Effect. Social Science Computer Review 35(3): 319-335.

Bloodgood, E., and J. Tremblay-Boire. 2017. Does Government Funding Depoliticize Non-governmental Organizations? Examining Evidence from Europe. European Political Science Review 9(3): 401-424.

Bob, C. 2005. The Marketing of Rebellion. Cambridge: Cambridge University Press.

Bob, C. 2012. The Global Right Wing and the Clash of World Politics. Cambridge: Cambridge University Press.

Bolleyer, N., and T. Börzel. 2010. Non-hierarchical Policy Coordination in Multilevel Systems. European Political Science Review 2(2): 157-185.

Bouwen, P. 2002. Corporate Lobbying in the European Union: The Logic of Access. Journal of European Public Policy 9(3): 365-390.

Brysk, A. (ed.). 2002. Globalization and Human Rights. Berkeley: University of California Press.

Buchanan, A., and R. Keohane. 2006. The Legitimacy of Global Governance Institutions. Ethics and International Affairs 20(4): 405-437.

Busby, J. 2007. Bono Made Jesse Helms Cry: Jubilee 2000, Debt Relief, and Moral Action in International Politics. International Studies Quarterly 51(2): 247-275.

Carpenter, R.C. 2007. Setting the Advocacy Agenda: Theorizing Issue Emergence and Nonemergence in Transnational Advocacy Networks. International Studies Quarterly 51(1): 99-120.

Carpenter, R.C. 2011. Vetting the Advocacy Agenda: Network Centrality and the Paradox of Weapons Norms. International Organization 65(1): 69-102.

Chalmers, A.W. 2013. Trading Information for Access: Informational Lobbying Strategies and Interest Group Access to the EU. Journal of European Public Policy 20(1): 39-58.

Clark, A. 1995. Non-Governmental Organizations and Their Influence on International Society. Journal of International Affairs 48: 507-525.

Clark, A.M. 2001. The Diplomacy of Conscience: Amnesty International and Changing Human Rights Norms. Princeton: Princeton University Press.

Cooley, A., and J. Ron. 2002. Organizational Insecurity and the Political Economy of Transnational Action. International Security 27(1): 5-39.

Dalton, R. 1994. The Green Rainbow: Environmental Groups in Western Europe. New Haven: Yale University Press.

Davis, C. 2004. International Institutions and Issue Linkage: Building Support for Agricultural Trade Liberalization. American Political Science Review 98(1): 153-169.

Dellmuth, L.M., and J. Tallberg. 2017. Advocacy Strategies in Global Governance: Inside vs. Outside Lobbying. Political Studies 65(3): 705-723. https://doi.org/10.1177/0032321716684356.

Dupuy, K., J. Ron, and A. Prakash. 2016. Hands Off My Regime! Governments' Restrictions on Foreign Aid to Non-governmental Organizations in Poor and Middle-Income Countries. World Development 84: 299-311.

Dür, A., and D. de Bièvre. 2007. The Question of Interest Group Influence. Journal of Public Policy 27(1): 1-12.

Dür, A., and G. Mateo. 2013. Gaining Access or Going Public? Interest Group Strategies in Five European Countries. European Journal of Political Research 52(5): 660-686.

European Union. 2018. Transparency and the EU. http://ec.europa.eu/transparencyregister/. Accessed 3 April 2018.

Evangelista, M. 1999. Unarmed Forces: The Transnational Movement to End the Cold War. Ithaca: Cornell University Press.

Feld, W. 1972. Nongovernmental Forces and World Politics. New York: Praeger Publishers.

Finnemore, M., and K. Sikkink. 1998. International Norm Dynamics and Political Change. International Organization 52(4): 887-917.

Florini, A. (ed.). 2000. The Third Force: The Rise of Transnational Civil Society. Washington, D.C.: The Carnegie Endowment for International Peace. 
Green, J.F., and G. Auld. 2017. Unbundling the Regime Complex: The Effects of Private Authority. Transnational Environmental Law 6 (2): 259-284.

Hadden, J. 2015. Networks in Contention: The Divisive Politics of Global Climate Change. Cambridge: Cambridge University Press.

Hadden, J., and L. Jasny. 2019. The Power of Peers: How Transnational Advocacy Networks Shape NGO Strategies on Climate Change. British Journal of Political Science 49(2): 637-659.

Halpin, Darren. 2002. Interest Groups and (Re)establishing Stability in Policy Making: The Case of the NSW Farmers' Association and the Native Vegetation Conservation Act. Australian Journal of Political Science 37(3): 489-508.

Halpin, D., and G. Jordan. 2009. Interpreting Environments: Interest Group Responses to Population Ecology Pressures. British Journal of Political Science 39(2): 243-265.

Hanegraaff, M. 2015. Transnational Advocacy over Time: Business and NGO Mobilization at UN Climate Summits. Global Environmental Politics 15(1): 83-104.

Hanegraaff M., Beyers J., and Braun C. 2011. Open the Door to More of the Same? The Development of Interest Group Representation atthe WTO. World Trade Review 10 (4): 447-472.

Hanegraaff, M., J. Beyers, and I. De Bruycker. 2016. Balancing Inside and Outside Lobbying: The Political Strategies of Lobbyists at Global Diplomatic Conferences. European Journal of Political Research 55(3): 568-588.

Heiss, A., and T. Johnson. 2016. Internal, Interactive, and Institutional Factors: A Unified Framework for Understanding International Nongovernmental Organizations. International Studies Review 18: $528-541$.

Hendrix, C., and W. Wong. 2012. When Is the Pen Truly Mighty? Regime Type and the Efficacy of Naming and Shaming in Curbing Human Rights Abuses. British Journal of Political Science 43(3): 651-672.

Hojnacki, M., D.C. Kimball, F.R. Baumgartner, J.M. Berry, and B.M. Leech. 2012. Studying Organizational Advocacy and Influence: Reexamining Interest Group Research. Annual Review of Political Science 15(9): 379-399.

Joachim, J. 2007. Agenda Setting, the UN, and NGOs: Gender Violence and Reproductive Rights. Washington: Georgetown University Press.

Keck, M.E., and K. Sikkink. 1998. Activists Beyond Borders: Advocacy Networks in International Politics. Ithaca, NY: Cornell University Press.

Keohane, R., and D. Victor. 2011. The Regime Complex for Climate Change. Perspectives on Politics 9(1): 7-23.

Klüver, H. 2011. The Contextual Nature of Lobbying: Explaining Lobbying Success in the European Union. European Union Politics 12(4): 483-506.

Lee, T. 2010. The Rise of International Nongovernmental Organizations: A Top-Down or Bottom-Up Explanation? Voluntas 21(3): 393-416.

Lindgren, K.-O., and T. Persson. 2011. Participatory Governance in the EU: Enhancing or Endangering Democracy and Efficiency?. London: Palgrave Macmillan.

Lohmann, S. 1998. The Information Rationale for the Power of Special Interests. American Political Science Review 92(4): 809-827.

Lowery, D., C. Poppelaars, and J. Berkhout. 2008. The European Union Interest System in Comparative Perspective: A Bridge Too Far? West European Politics 31(6): 1231-1252.

Lowi, T. 1964. American Business, Public Policy, Case Studies, and Political Theory. World Politics 16: 677-715.

Mahoney, C., and F. Baumgartner. 2008. Converging Perspectives on Interest Group Research in Europe and North America. West European Politics 6: 1253-1273.

March, J., and J.O. Olsen. 1984. The New Institutionalism: Organizational Factors in Political Life. American Political Science Review 78(3): 734-749.

Martens, K. 2002. Mission Impossible? Defining Nongovernmental Organizations. Voluntas 13(3): 271-285.

McCarthy, John D., and Mayer N. Zald. 1978. Resource Mobilisation and Social Movements: A Partial Theory. American Journal of Sociology 82: 1212-1241.

McNamara, K.R. 1999. The Currency of Ideas: Monetary Policy in the European Union. Ithaca: Cornell University Press.

Mearsheimer, J. 1994. The False Promises of International Institutions. International Security 19: 5-49.

Mitchell, G.E., and H. Schmitz. 2014. Principled Instrumentalism: A Theory of Transnational NGO Behavior. Review of International Studies 40(3): 487-504. 
Morse, J., and R. Keohane. 2014. Contested Multilateralism. The Review of International Organizations 9(4): 385-412.

Murdie, A., and D. Davis. 2012. Looking in the Mirror: Comparing INGO Networks Across Issue Areas. Review of International Organizations 7(2): 177-202.

Orsini, A. 2013. Institutional Fragmentation and the Influence of "Multi-forum" Non-state Actors: Navigating the Regime Complexes for Forestry and Genetic Resources. Global Environmental Politics 13(3): 34-55.

Pallas, C., and A. Uhlin. 2014. Civil Society Influence on International Organizations: Theorizing the State Channel. Journal of Civil Society 10(2): 184-203.

Petersson, M.T., L.M. Dellmuth, A. Merrie, and H. Österblom. 2018. Patterns and Trends in Non-state Actor Participation in Regional Fisheries Management Organizations. Marine Policy 104: 146-156.

Prakash, A., and M.K. Gugerty (eds.). 2010. Advocacy Organizations and Collective Action. Cambridge: Cambridge University Press.

Prakash, A., and M. Potoski. 2014. Global Private Regimes, Domestic Public Law: ISO 14001 and Pollution Reduction. Comparative Political Studies 47(3): 369-394.

Pralle, S. 2006. Branching Out, Digging In: Environmental Advocacy and Agenda Setting. Washington: Georgetown University Press.

Raustiala, K. 1997. States, NGOs, and International Environmental Institutions. International Studies Quarterly 41(4): 719-740.

Reimann, K.D. 2006. A View from the Top: International Politics, Norms and the Worldwide Growth of NGOs. International Studies Quarterly 50(1): 45-68.

Risse, T. 2012. Transnational Actors and World Politics. In Handbook of International Relations, 2nd ed, ed. W. Carlsnaes, T. Risse, and B.A. Simmons. London: Sage.

Risse, T., S. Ropp, and K. Sikkink (eds.). 2015. The Persistent Power of Human Rights: From Commitment to Compliance. Cambridge: Cambridge University Press.

Risse-Kappen, T. (ed.). 1995. Bringing Transnational Relations Back In. Cambridge: Cambridge University Press.

Scholte, J.A. 2017. Polycentrism and Democracy in Internet Governance. In The Net and the Nation State: Multidisciplinary Perspectives on Internet Governance, ed. U. Kohl. Cambridge: Cambridge University Press.

Sell, S.K., and A. Prakash. 2004. Using Ideas Strategically: The Contest Between Business and NGO Networks in Intellectual Property Rights. International Studies Quarterly 48(1): 143-175.

Skjelsbaek, K. 1971. The Growth of International Non-Governmental Organizations in the Twentieth Century. International Organization 25: 420-442.

Skodvin, T., and S. Andresen. 2008. Nonstate Influence in the International Whaling Commission. In NGO Diplomacy: The Influence of Nongovernmental Organizations in International Environmental Negotiations, ed. M.M. Betsill and E. Corell, 1970-1990. Cambridge: MIT Press.

Smith, J., and D. Wiest. 2005. The Uneven Geography of Global Civil Society: National and Global Influences on Transnational Association. Social Forces 84(2): 621-652.

Stevenson, H. 2016. The Wisdom of the Many in Global Governance: An Epistemic-Democratic Defense of Diversity and Inclusion. International Studies Quarterly 60: 400-412.

Stroup, S. 2012. Borders Among Activists. Ithaca, NY: Cornell University Press.

Stroup, S., and W.H. Wong. 2017. The Authority Trap. Ithaca: Cornell University Press.

Tallberg, J., L.M. Dellmuth, A. Duit, and H. Agné. 2018. NGO Influence in International Organizations: Information, Access, and Exchange. British Journal of Political Science. https://doi.org/10.1017/ S000712341500037X.

Tallberg, J., T. Sommerer, T. Squatrito, and C. Jönsson. 2013. The Opening Up of International Organizations: Transnational Access in Global Governance. Cambridge: Cambridge University Press.

Tarrow, S. 2005. The New Transnational Activism. Cambridge: Cambridge University Press.

United Nations. 2016. List of Non-Governmental Organizations in Consultative Status with the Economic and Social Council as of 1 September 2016. Economic and Social Council, E/2016/INF/5. http://undocs.org/E/2016/INF/5. Accessed 3 April 2018.

World Bank. 2018. Civil Society. www.worldbank.org/en/about/partners/civil-society. Accessed 3 April 2018.

Yanacopulos, H. 2005. The Strategies that Bind: NGO Coalitions and Their Influence. Global Networks 5: $93-110$.

Zelli, F. 2011. The Fragmentation of the Climate Governance Architecture. Wiley Interdisciplinary Reviews: Climate Change 2(2): 255-270. 
Publisher's Note Springer Nature remains neutral with regard to jurisdictional claims in published maps and institutional affiliations. 